\title{
Ecological implications of mass growth of benthic cyanobacteria in rivers
}

\author{
S. Sabater ${ }^{1,2, *}$, E. Vilalta ${ }^{2}$, A. Gaudes ${ }^{2}$, H. Guasch ${ }^{1}$, I. Muñoz ${ }^{2}$, A. Romaní ${ }^{1}$ \\ ${ }^{1}$ Department of Environmental Sciences and Institute of Aquatic Ecology, University of Girona, Campus Montilivi, \\ 17071 Girona, Spain \\ ${ }^{2}$ Department of Ecology, University of Barcelona, Avinguda Diagonal 645, 08028 Barcelona, Spain
}

\begin{abstract}
The environmental and biological factors related to the wax and wane of benthic cyanobacteria were analysed in a river system (Llobregat River, NE Spain) with high nutrient content and low discharge. The cyanobacterial masses grew from early January to the end of May in shallow areas and extended progressively towards the riffle zones. Significant fractions of the mats became progressively unattached and free-floating, dispersing downstream and showing different structural and physiological characteristics. Chlorophyll a was slightly higher for the free-floating $(34.6 \pm 19 \mu \mathrm{g}$ $\mathrm{cm}^{-2}$ ) than for the attached compartments $\left(24.9 \pm 19.5 \mu \mathrm{g} \mathrm{cm}^{-2}\right)$. The exoenzymatic $\beta$-glucosidase, phosphatase (APA) and aminopeptidase (AMA) activities were higher in the free-floating than in the attached mats. The low APA:AMA ratio indicated that nitrogen limitation could affect both the attached and the free-floating mats. This situation was coincident with a peak in geosmin production, suggesting that nitrogen limitation could trigger the increase of geosmin in the cyanobacterial mats. The decay dynamics of the free-floating mats was revealed by higher AMA and $\beta$-glucosidase activities, which could be activated by the release of proteinaceous and polysaccharidic compounds of degrading cells. The degradation processes occurring within the mat could favour geosmin release into the water. Moreover, the large number of meiofauna in the free-floating mat could contribute both to the degradation process and to the release and diffusion of the geosmin in the river.
\end{abstract}

KEY WORDS: Cyanobacteria · Geosmin · Exoenzyme activities · Nutrient limitation · Chlorophyll Resale or republication not permitted without written consent of the publisher

\section{INTRODUCTION}

While factors associated with cyanobacteria occurrence and its wax and wane in the water column have been exhaustively studied in lakes (Reynolds 1999), much less information has been gathered on benthic mass growths. While planktonic cyanobacteria have often been found to be related to toxin occurrence (Codd 1995), this link is much less common in benthic habitats (but see Mez et al. 1998, Baker et al. 2001, Hamill 2001). Cyanobacterial mass growths in rivers may be associated with water quality problems (Sabater et al. 2000). In many instances, mass development of cyanobacteria have been associated with odours and flavours in the water (Izaguirre \& Taylor 1995, Young et al. 1996). The production of unpleasant (e.g. odorous) or toxic metabolites has been placed in the ecological context of competition and uncoupling between nutrient availability and biomass accumulation (Paerl \& Millie 1996). However, to link the occurrence of nuisance metabolites with the scarcity of resources may be difficult in microbial mats, where a tight package of cells and associated diffusion problems may complicate the observations (Sabater et al. 2002). This may be particularly true for cyanobacterial mats, which are characterised by steep and fluctuating light and oxygen gradients (Stal 1995, Pringault \& Garcia Pichel 2000).

Benthic mats may undergo a process involving growth, the occupation of the river surface area and subsequent detachment and drift. This is the case of the Llobregat River, NE Spain, a shallow, nutrient-rich 
river that experiences seasonal growths and collapses of cyanobacterial masses. In addition, the dynamic changes are accompanied by a high production of geosmin by the cyanobacterial mats and may be related to the fate of the metabolites in a river context (Vilalta et al. 2003). To determine the factors related to the wax and wane of cyanobacteria in the river as well as the associated dynamics of nuisance metabolites, the following questions have been raised: (1) Is there a relationship between the dynamics of the mats and their consumption of inorganic nutrients? (2) Does such a relationship hold for the geosmin production dynamics? (3) Is there any correlation between the apparently limiting nutrients and the physiological characteristics of these mats? (4) What is the significance, if any, of the attached and unattached fractions of the cyanobacterial mat concerning geosmin occurrence? and (5) Is there any relationship between other trophic levels and the dynamics of the cyanobacterial mats and of their produced metabolites? These questions are placed in the context of a field-based study, where the community dynamics of algae and cyanobacteria are studied from both structural and functional perspectives.

\section{MATERIALS AND METHODS}

Sampling strategy. The study was carried out in the Llobregat River, Catalonia, NE Spain, in an area of intense water demand. In its watershed, several industrial and urban centres affect both water quality and flow. Geosmin occurrence was detected several years ago and was found to be the culprit for constant problems in water quality (Vilalta et al. 2003). Since the waters of the Llobregat River are used for human consumption, the presence of geosmin has forced the use of sophisticated water treatments to reach acceptable purification standards (Alcaraz et al. 2002). A previously studied site with a high development of cyanobacterial mats was selected (Site P2, Vilalta et al. 2003). This site is located $60 \mathrm{~km}$ upstream of the river mouth and ca. $20 \mathrm{~km}$ upstream from a water treatment plant, where water is collected and treated for human consumption.

During winter and spring 2002 (January to May 2002) geosmin and environmental factors were monitored weekly at Site P2. Algal mat samples were collected from the attached and the free-floating mats with a PVC corer. Samples for algal and meiofauna composition were fixed in $4 \%$ formalin. Algal mat samples for chlorophyll a (chl a) concentration estimation, geosmin and structural analysis (polysaccharides, $\mathrm{C} / \mathrm{N} / \mathrm{P}$ content and scanning electron microscopy [SEM]) were frozen in the field in liquid nitrogen.
Samples for measuring extracellular enzyme activities were also collected and preserved at low temperature until analysis. Additionally, algal mat samples for measuring fluorescence in the dark were collected and measurements were performed in the field.

Physical and chemical analyses. Physical and chemical measurements were performed separately at the littoral and faster-flowing (riffle) zones. Therefore, on each sampling date, water temperature, $\mathrm{pH}$, conductivity and dissolved oxygen (\%) were measured in the 2 habitats with a MultiLine F/SET-3 (WTW Multiline F/SET-3). Incident light was measured at the same frequency using a Li-Cor quantum sensor (Li-192SB). The light extinction coefficient was calculated by relating the light irradiance at the water surface and that reaching the streambed. Water velocity was measured with a current meter (MiniAir2 Schiltknecht 43221) at the 2 habitats. Filtered water samples (using Whatman GF/F filters; 3 replicates for each analysis) were taken in order to analyse inorganic nutrients in the littoral and riffle zones. Nitrate, nitrite, ammonium, sulphate and chloride were analysed using an ion chromatograph (Kontron) equipped with an IC-Pack anion column $(4.5 \times 50 \mathrm{~nm})$ and an ultraviolet detector. Soluble reactive phosphorus (SRP) was analysed spectrophotometrically (Perkin-Elmer Lambda2 UV/VIS spectrophotometer) following the procedure described by Grasshoff et al. (1983).

Geosmin analysis. Geosmin in the water and in the mats was analysed according to Vilalta et al. (2003). Geosmin content in the mats was analysed after grinding and subsequent methanol extraction (Durrer et al. 1999).

Algal composition and abundance. Algal mat subsamples (3 replicates) were collected from the attached and the free-floating mats with a small PVC corer $\left(3.1 \mathrm{~cm}^{2}\right)$ which was introduced into each mass. Samples were fixed with formalin and observed under a light microscope using a Reichert Polyvar at $500 \times$ to study the community composition and abundance. The abundance of algal cells was determined after dispersion of the sample using a sonication bath (Selecta $40 \mathrm{~W}$ power, $40 \mathrm{kHz}$ ultrasound frequency) and determining an aliquot. Subsamples from the attached and free-floating cyanobacterial mats were observed with SEM after being freeze-dried and covered with carbon and gold. A Hitachi S-2000 SEM was used, operated at $7 \mathrm{kV}$.

Chl a concentration. Chl a concentration was measured on subsamples from the attached and freefloating mats. Measurements were carried out after extraction in $90 \%$ acetone and sonication (4 min). Up to 3 successive extractions were necessary in some mats to achieve complete extraction of the chl a. For each sampling date, 3 to 5 replicates were used. Chl a concentration was determined spectrophotometrically 
(Perkin-Elmer, Lambda UV/VIS spectrophotometer) following Jeffrey \& Humphrey (1975) after filtration (Whatman GF/F) of the extract. Chl a was expressed by surface area, dry weight (DW) and ash-free dry weight (AFDW).

In vivo fluorescence. The maximum photosynthetic capacity (photon yield) in the dark for the different mats (attached, free-floating, brown growth) was estimated in the field using Pulse Amplitude Modulation (PAM) fluorescence (Hofstraat et al. 1994). Estimates were performed by taking cyanobacterial mats collected in full sunlight (i.e. light saturated at 12:00 h) and placing them in the dark for $30 \mathrm{~min}$. Five replicates were considered for each sampling date. The cyanobacterial mats were placed in the bottom of $20 \mathrm{ml}$ glass vials with the top side facing up and immersed in $10 \mathrm{ml}$ of river water. Glass vials were placed directly on top of the optical fiberoptics. Photon yield was calculated as the average of the 5 measurements.

Enzymatic activity. The potential extracellular enzyme activity of leucine-aminopeptidase (AMA), $\beta$ glucosidase and phosphatase (APA) were measured using fluorescent-linked substrates (methylumbelliferyl, MUF). Aminomethyl-coumarin (AMC) was used for the peptidase. Algal mats were placed at $4{ }^{\circ} \mathrm{C}$ and transported to the laboratory. Once there (within $2 \mathrm{~h}$ ), the mats were incubated $(1 \mathrm{~h})$ with the substrates in the dark at river temperature. Incubations were performed at saturation conditions $(300 \mu \mathrm{M})$. Blanks and standards of MUF and AMC (0 to $100 \mu \mathrm{M}$ ) were also incubated. At the end of the incubation, glycine buffer $\mathrm{pH} 10.4$ was added (1:1, v:v) and the fluorescence was measured at 365/455 nm excitation/emission for MUF and 364/ $445 \mathrm{~nm}$ excitation/emission for AMC. All substrates and standards were prepared with filter-sterilised river water (Whatman GF/F and $0.2 \mu \mathrm{m}$ pore-size cellulose nitrate membrane filters). At the end of the incubation, samples were dried $\left(48 \mathrm{~h}\right.$ at $\left.110^{\circ} \mathrm{C}\right)$, and burned $(4 \mathrm{~h}$ at $450^{\circ} \mathrm{C}$ ), to express the activity in $\mu \mathrm{mol}$ (of MUF or AMC released) per unit organic matter per hour.

Structural measurements. Total carbohydrates, phosphorus, carbon and nitrogen were measured for the attached, free-floating and brown mats collected on 2 sampling dates: before the geosmin peak (14 January 2002) and during the peak (20 March 2002). Total carbohydrates were measured by the phenol-sulphuric assay (Dubois et al. 1956). About $10 \mathrm{mg}$ DW of ground sample (3 replicates) was used for each analysis. After extraction, samples were filtered (precombusted, Whatman GF/F filters) and absorbance was measured at $485 \mathrm{~nm}$ against a reagent blank. Standards of glucose ( 0 to $200 \mu \mathrm{g} \mathrm{ml}^{-1}$ ) were also prepared and the results were given as glucose equivalents. Total phosphorus content in the mats was measured by analysing the SRP (colorimetric ascorbic acid method) after the digestion of the sample with peroxidisulphate potassium in sodium hydroxide (Grasshoff et al. 1983). About $50 \mathrm{mg}$ DW of ground sample (3 replicates) diluted with $30 \mathrm{ml}$ of distilled water were used for each phosphorus analysis. Total $\mathrm{C}$ and $\mathrm{N}$ content was measured by a $\mathrm{C} / \mathrm{N}$ analyser 1500 Carlo Erba using vanadium pentoxide as the oxidation catalyser. About 5 to $10 \mathrm{mg}$ DW of ground sample (3 replicates) was used for each analysis.

Meiofauna. Three replicate subsamples were taken from the different mats (attached and free-floating). These were all immediately fixed in $4 \%$ formaldehyde. In the laboratory, samples were passed consecutively through different sized mesh sieves $(250,100$ and $50 \mu \mathrm{m})$ to obtain the corresponding size fractions. All fractions were counted and identified under a stereomicroscope, except for the $50 \mu \mathrm{m}$ fraction, which was observed and counted under an inverted microscope. Estimates were given as the sum of the different fractions.

Statistical analyses. A correlation analysis (Pearson coefficient) was performed to determine possible relationships between the variables. A 1-way ANOVA with repeated measures (using the attached vs freefloating mats as a factor) was used to detect significant differences of environmental and biological variables with time (Winer 1971).

\section{RESULTS}

\section{Physical and chemical characteristics of the water}

Benthic cyanobacteria developed primarily in littoral areas or immediately downstream of dams, where waters were shallow and slow-moving (Table 1). There were differences between the littoral areas and the riffle sections (with faster-moving water) in terms of water velocity (1-way ANOVA, $F=294.8$, $p=0.00001$ ), but there were no significant differences in water chemistry (Table 1). Light availability was slightly higher in the littoral than in the riffle areas (Table 1). Water flow during the growth period of the cyanobacterial mats was low $\left(0.25\right.$ to $\left.0.27 \mathrm{~m}^{3} \mathrm{~s}^{-1}\right)$ and the waters were characterised (Table 1) by higher phosphorus and lower dissolved inorganic nitrogen levels (lower $\mathrm{N}: \mathrm{P}$ ratios) than in the immediately previous period (Vilalta el al. 2003).

\section{Composition and abundance of benthic algal and cyanobacterial communities}

The onset of benthic cyanobacteria started in midJanuary and lasted until the end of May (Table 2). Prior 
to the cyanobacterial mass development, diatom communities predominated, producing brown mats which covered the riverbed. During the growth period of the benthic cyanobacteria, the brown mats decreased in

Table 1. Physico- and chemical data of the Llobregat River waters during the period of maximum growth of the cyanobacterial mats (19 February to 2 April). Data are averages for the littoral and riffle areas studied in the river $(\mathrm{n}=7)$. C:N is expressed as the molar ratio. DOC: dissolved organic carbon. Significant differences between riffle and littoral are indicated for each variable as ${ }^{*} \mathrm{p}<0.05,{ }^{* * *} \mathrm{p}<0.0001$

\begin{tabular}{|lccccc|}
\hline \multirow{2}{*}{ Variables } & \multirow{2}{*}{ Units } & \multicolumn{2}{c}{ Riffle } & \multicolumn{2}{c|}{ Littoral } \\
& & Mean & $\mathrm{SD}$ & Mean & $\mathrm{SD}$ \\
\hline Geosmin & $\mathrm{ng} \mathrm{l^{-1 }}$ & 159.5 & 40.2 & & \\
$\mathrm{pH}$ & & 8.3 & 0.2 & 8.3 & 0.4 \\
Temperature & ${ }^{\circ} \mathrm{C}$ & 10.8 & 2.8 & 13.2 & 4.0 \\
$\mathrm{O}_{2}$ (conc.) & $\mathrm{mg} \mathrm{l}^{-1}$ & $10.6^{*}$ & 0.8 & $14.3^{*}$ & 3.3 \\
$\mathrm{O}_{2}$ (percentage) & $\%^{-1}$ & $97.1^{*}$ & 8.5 & $141.07^{*}$ & 45.6 \\
Light extinction $^{-1}$ & $\mathrm{~m}^{-1}$ & 0.7 & 0.2 & 1.1 & 0.7 \\
Velocity & $\mathrm{cm} \mathrm{s}^{-1}$ & $33.0^{* * *}$ & 9.4 & $1.0^{* * *}$ & 0.7 \\
$\mathrm{DOC}^{-1}$ & $\mathrm{mg} \mathrm{l}^{-1}$ & 3.6 & 2.70 & 2.79 & 0.96 \\
$\mathrm{Cl}^{-}$ & $\mathrm{mg} \mathrm{l}^{-1}$ & 244.1 & 30.9 & 247.5 & 26.0 \\
$\mathrm{SO}_{4}{ }^{2-}$ & $\mathrm{mg} \mathrm{l}^{-1}$ & 101.0 & 12.4 & 99.3 & 6.5 \\
$\mathrm{NO}_{3}{ }^{-}$ & $\mathrm{mg} \mathrm{l}^{-1}$ & 3.9 & 0.8 & 3.8 & 0.9 \\
$\mathrm{NO}_{2}{ }^{-}$ & $\mathrm{mg} \mathrm{l}^{-1}$ & 0.1 & 0.02 & 0.11 & 0.02 \\
$\mathrm{NH}_{4}{ }^{-}$ & $\mathrm{mg} \mathrm{l}^{-1}$ & 0.1 & 0.03 & 0.09 & 0.02 \\
$\mathrm{PO}_{4}{ }^{3-}$ & $\mathrm{mg} \mathrm{l}^{-1}$ & 0.4 & 0.08 & 0.38 & 0.05 \\
$\mathrm{~N}^{-}$ & & 18.0 & 3.7 & 17.8 & 4.4 \\
& & & & & \\
\hline
\end{tabular}

extent, but remained present in the riffle zones. This mat was composed of 80 to $100 \%$ diatoms, mainly of the genera Navicula and Nitzschia. The cyanobacterial masses grew in thickness and extension, covering up to $70 \%$ of the total riverbed surface area in the studied site. Their growth began in the shallow areas (current velocity not much higher than 1 $\mathrm{cm} \mathrm{s}^{-1}$ ) and extended progressively towards the riffle zones (avoiding, however, the areas with currents that were too fast). The growth dynamics of the benthic cyanobacterial mats meant that significant fractions of the attached mats became unattached and free-floating. These fractions later drifted downstream and were observed throughout the downstream area of the studied site. This detachment process increased as cyanobacterial growth increased. Finally, the cyanobacterial mass growth collapsed when waters became warmer and flow increased towards the end of May. Under these conditions, another community of green algae, dominated by Cladophora, replaced the cyanobacterial mats.

The community composition of the cyanobacterial mats was fairly similar in the attached and the free-floating fractions (Table 2). In both, the dominant components were the cyanobacteria

Table 2. Community composition and total cell density of the algal and cyanobacterial community in the attached and freefloating mats developing in the Llobregat River during the study period (January to May 2002). Values expressed as the percentage contribution of the different taxa or groups to the total density (with the exception of Vaucheria, where abundance is expressed as mm filament $\mathrm{cm}^{-2}$ ). Presence is expressed by +

\begin{tabular}{|c|c|c|c|c|c|c|c|c|c|c|c|c|}
\hline & \multicolumn{6}{|c|}{ Attached mat } & \multicolumn{6}{|c|}{ Free-floating mat } \\
\hline & 14 Jan & $11 \mathrm{Feb}$ & 4 Mar & 20 Mar & $22 \mathrm{Apr}$ & 20 May & 14 Jan & 11 Feb & 4 Mar & 20 Mar & 22 Apr & 20 May \\
\hline Total density $\left(\right.$ cells $\left.\mathrm{cm}^{-2}\right) \times 10^{6}$ & 7.1 & 14.0 & 2.2 & 4.2 & 4.1 & 1.3 & 28.6 & 38.6 & 110.6 & 20.3 & 42.3 & 5.3 \\
\hline \multicolumn{13}{|l|}{ Cyanobacteria } \\
\hline Geitlerinema sp. & & & & & & & & 3.0 & 0.4 & & 0.2 & \\
\hline Merismopedia glauca & & 1.7 & & & & & 0.1 & 0.1 & 0.1 & & & 1.7 \\
\hline Microcoleus sp. & 1.3 & & & & & & & & & & & \\
\hline Oscillatoria limosa (Ag. Ex. Gom.) & 37.3 & 69.3 & 51.1 & 61.0 & 42.9 & 11.1 & 55.7 & 44.9 & 76.0 & 90.7 & 79.8 & 32.7 \\
\hline O. aff tenuis (morph.1) (Ag. ex. Gom.) & 8.8 & 0.7 & & 6.5 & 19.7 & 26.7 & 13.4 & 0.7 & 0.5 & & 6.5 & 18.3 \\
\hline O. aff tenuis (morph.2) (Ag. ex. Gom.) & & & & 1.5 & 1.5 & 2.4 & 2.2 & 9.9 & 1.5 & 0.3 & 0.3 & 10.8 \\
\hline Phormidium sp. (Kütz. ex Gom.) & 7.6 & & & & 9.6 & 2.9 & 6.1 & 0.2 & 0.1 & & 1.0 & \\
\hline Pseudoanabaena catenata Lauterborn & 14.0 & 16.2 & & & & 13.0 & 15.0 & 35.4 & 17.8 & 1.5 & 5.6 & 1.9 \\
\hline Spirulina maior Kütz. & & & & & & & & 0.4 & & & 1.1 & 1.0 \\
\hline \multicolumn{13}{|l|}{ Algae } \\
\hline Cladophora glomerata ((Linn.) Kütz.) & & & & & & & & & 0.1 & & & \\
\hline Closterium sp. & + & + & & & & + & + & + & + & & + & + \\
\hline Euglena sp. & & & 2.6 & 0.1 & & & & & + & + & + & + \\
\hline Klebsormidium sp. (Silva, Matt. et Black & & & & & 2.3 & & & 3.3 & 1.1 & 0.4 & & \\
\hline Oedogonium sp. & & & & & 1.3 & 0.1 & & & 0.1 & 2.0 & + & \\
\hline Scenedesmus sp. & & 0.1 & & & & 0.5 & & + & & + & & \\
\hline Spirogyra sp. & & & & & 0.6 & & & + & + & + & 0.1 & \\
\hline Vaucheria sp. $\left(\mathrm{mm} \mathrm{cm}^{-2}\right)$ & 1150 & 2265 & 10151 & 4807 & 71700 & & 3225 & 657 & 7790 & 796 & 352 & \\
\hline Diatoms & 31.1 & 12.1 & 46.2 & 31.0 & 21.9 & 43.2 & 7.4 & 2.1 & 2.4 & 4.9 & 5.3 & 33.4 \\
\hline
\end{tabular}


Table 3. Values of C:N (molar ratio), carbon, nitrogen, phosphorus and glucose (carbohydrate estimate) as well as ash content from the different mat compartments studied in the Llobregat River for selected dates. All values \pm SD

\begin{tabular}{|c|c|c|c|c|c|c|c|}
\hline $\begin{array}{l}\text { Date } \\
(\mathrm{d} / \mathrm{mo} / \mathrm{yr})\end{array}$ & Mat & $\mathrm{C}: \mathrm{N}$ & $\begin{array}{c}\mu \mathrm{g} \mathrm{C} \mathrm{\textrm {mg } ^ { - 1 }} \\
\text { DW }\end{array}$ & $\begin{array}{l}\mu \mathrm{g} \mathrm{N} \mathrm{mg} \mathrm{N}^{-1} \\
\mathrm{DW}\end{array}$ & $\begin{array}{l}\mu \mathrm{g} \mathrm{P} \mathrm{\textrm {mg } ^ { - 1 }} \\
\text { DW }\end{array}$ & $\begin{array}{c}\mu g \text { glucose } \mathrm{mg}^{-1} \\
\text { DW }\end{array}$ & $\%$ ash \\
\hline 14/01/02 & Attached & $107 \pm 42$ & $720 \pm 244.1$ & $6.1 \pm 1.7$ & $1.2 \pm 0.4$ & $11.2 \pm 2.5$ & $95.0 \pm 0.5$ \\
\hline 14/01/02 & Brown & $134 \pm 76$ & $590.5 \pm 290.3$ & $3.9 \pm 0.8$ & $0.9 \pm 0.2$ & $10.3 \pm 0.7$ & $91.9 \pm 1.4$ \\
\hline 20/03/02 & Attached & $151 \pm 87$ & $329.4 \pm 173.4$ & $1.9 \pm 0.2$ & $0.6 \pm 0.09$ & $5.9 \pm 0.6$ & $95.1 \pm 0.5$ \\
\hline $20 / 03 / 02$ & Free-floating & $96 \pm 77$ & $1119.7 \pm 535.1$ & $12.9 \pm 9.5$ & $2.2 \pm 1.5$ & $27.4 \pm 18.9$ & $84.7 \pm 7.1$ \\
\hline 20/03/02 & Brown & $41 \pm 46$ & $557.6 \pm 401.9$ & $16.8 \pm 7.9$ & $3.1 \pm 0.5$ & $35.8 \pm 13.0$ & $84.1 \pm 3.5$ \\
\hline
\end{tabular}

Oscillatoria limosa and Oscillatoria tenuis. However, Vaucheria sp. was also abundant in the attached mat, while it was less frequent in the free-floating one. A few diatoms formed part of the cyanobacterial mats throughout the whole period, but to a much lesser extent in the free-floating mat. SEM observations and ash content determined that inorganic particles were less abundant in the free-floating mat (Table 3), and its porosity was higher (Fig. 1). The structural differences were obvious when the polysaccharides, nitrogen and phosphorus in the 2 fractions were analysed (Table 3 ). All of these structural components were consistently higher in the free-floating mat $(\mathrm{p}=0.05, \mathrm{p}=0.027, \mathrm{p}=$ 0.046 , respectively). The percent of inorganic particles was lower in the free-floating mat, but differences were not significant.

Chl $a$ in the attached and free-floating cyanobacterial mats ranged from 30 to $50 \mu \mathrm{g} \mathrm{cm}^{-2}$ for most of the period (Fig. 2). The differences described above in structure and composition resulted in a slightly higher (not statistically significant) chl a content for the freefloating mat, both with reference to surface area (34.6 \pm 19 and $24.9 \pm 19.5 \mathrm{SD} \mu \mathrm{g} \mathrm{cm}^{-2}$, respectively) or

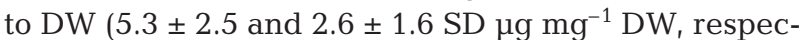

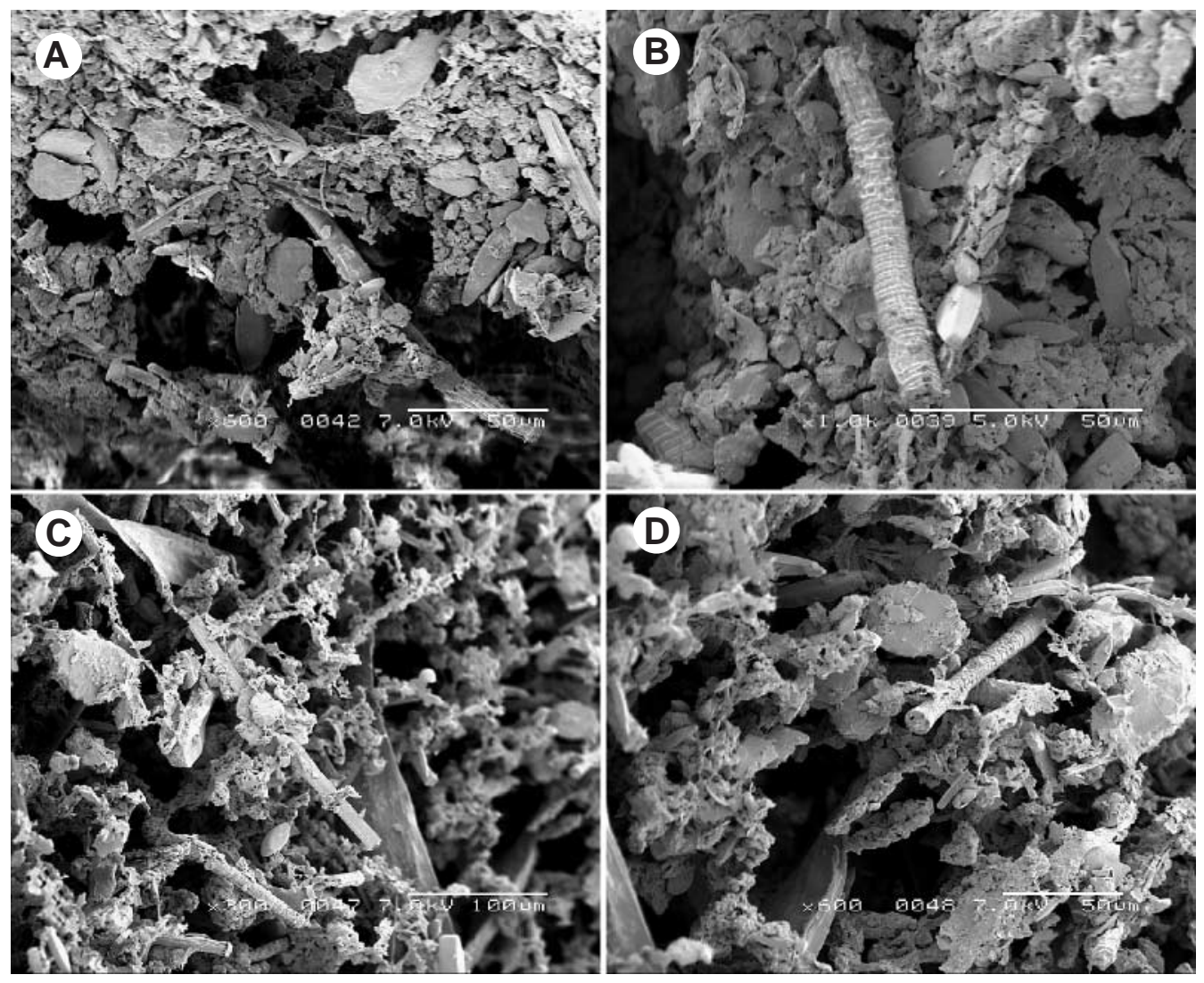

Fig. 1. SEM photographs of freeze-dried samples of $(A, B)$ attached and $(C, D)$ free-floating cyanobacterial mats in the Llobregat River 


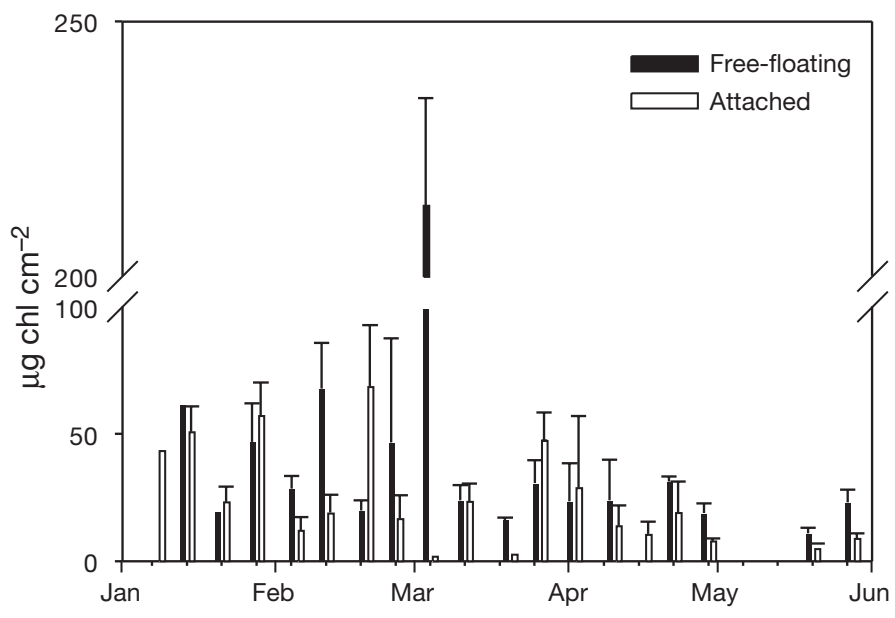

Fig. 2. Chlorophyll a dynamics $\left(\mu \mathrm{g} \mathrm{chl} \mathrm{cm}^{-2}\right.$ ) in the attached and free-floating compartments of the cyanobacterial mats in the Llobregat River

tively). Chl a concentration of the attached fraction was positively correlated with water nutrient content (nitrate: $\mathrm{r}=0.501, \mathrm{p}=0.04$; ammonia: $\mathrm{r}=0.502, \mathrm{p}=$ 0.04; reactive phosphorus: $r=0.52, p=0.029, n=17$ ). Similar relationships were not observed between chl $a$ and water nutrients for the free-floating fraction.

There was a notable difference in geosmin concentration between the attached mat $(0.55 \pm 0.97 \mathrm{SD}$ ng geosmin $\left.\mathrm{mg}^{-1} \mathrm{DW}\right)$ and the free-floating mat (5.25 \pm $4.96 \mathrm{SD}$ ng geosmin $\left.\mathrm{mg}^{-1} \mathrm{DW}\right)$. This difference was statistically significant (1-way ANOVA, $F=14.67, \mathrm{p}=$ 0.0005). Geosmin concentration in the free-floating mat was correlated to the cell density $(r=0.884, p=$ 0.019), but this was not so in the attached mat.

\section{Activity measurements in the mat}

Enzymatic activities showed distinct patterns throughout the period of cyanobacterial mass growth (Fig. 3). $\beta$-glucosidase was low during the period of maximum geosmin production (Vilalta et al. 2003) and increased during the initial and final periods of cyanobacterial growth. $\beta$-glucosidase activity was higher (repeated measures ANOVA, $\mathrm{p}=0.012$ ) in the freefloating mats (average of $2.4 \pm 2.2 \mathrm{SD} \mu \mathrm{mol} \mathrm{MUF} \mathrm{g}^{-1}$ organic matter $[\mathrm{OM}] \mathrm{h}^{-1}$ ) than in the attached ones $\left(2.2 \pm 2.5 \mathrm{SD} \mu \mathrm{mol}\right.$ MUF $\left.\mathrm{g}^{-1} \mathrm{OM} \mathrm{h}^{-1}\right)$. APA was very high at the onset of the cyanobacterial episode and progressively decreased. APA was higher in the freefloating mat (average of $3.8 \pm 2.2 \mathrm{SD} \mu \mathrm{mol} \mathrm{MUF} \mathrm{g}^{-1}$ $\mathrm{OM} \mathrm{h}^{-1}$ ) than in the attached mat (average of $3.1 \pm 2.3$ SD $\mu$ mol MUF $g^{-1} \mathrm{OM} \mathrm{h}^{-1}$ ), the differences being significant (repeated measures ANOVA, $p=0.033$ ). APA was correlated with chl a concentration $(\mathrm{r}=0.657, \mathrm{p}=$
0.003) in the attached mat, but not in the free-floating mat. Finally, AMA was 3 times higher in the freefloating mat (average of $35.3 \pm 8.6 \mathrm{SD} \mu \mathrm{mol} \mathrm{AMC} \mathrm{mg}^{-1}$ $\mathrm{OM} \mathrm{h}^{-1}$ ) than in the attached mat (average of $17.9 \pm$ 13.4 SD $\mu \mathrm{mol}$ AMC $\mathrm{mg}^{-1} \mathrm{OM} \mathrm{h}^{-1}$ ). These differences were highly significant (repeated measures ANOVA, $\mathrm{p}=0.0001$ ). The diatom-dominated community (brown
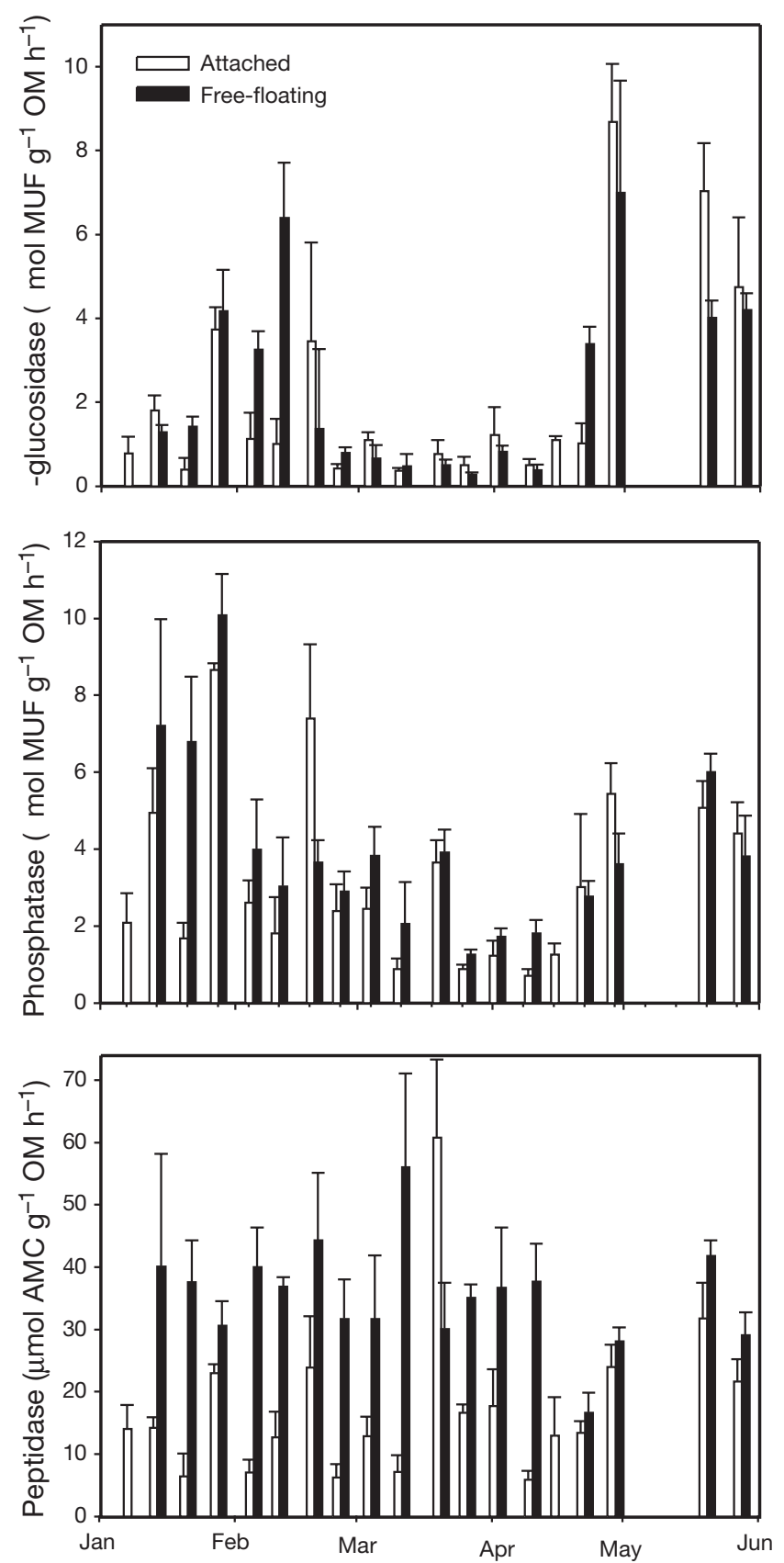

Fig. 3. Exoenzyme activities ( $\beta$-glucosidase, alkaline phosphatase and peptidase) using the studied period in the Llobregat River for the attached and the free-floating cyanobaterial mats. OM: organic matter 
film) that co-occurred with the cyanobacterial mats had a similar $\beta$-glucosidase activity $\left(2.3 \pm 1.5\right.$ SD $\mu$ mol MUF $\mathrm{g}^{-1} \mathrm{OM}$ $\left.\mathrm{h}^{-1}\right)$, but a much higher APA $(6.2 \pm 2.2 \mathrm{SD}$ $\mu$ mol MUF $\mathrm{g}^{-1} \mathrm{OM} \mathrm{h}^{-1}$ on average) than the free-floating mat. In contrast, AMA in the free-floating mat exceeded that of the brown mats $\left(26.1 \pm 8.1 \mathrm{SD} \mu \mathrm{mol} \mathrm{AMC}^{-1}\right.$ $\mathrm{OM} \mathrm{h}^{-1}$ ). The APA:AMA ratio was lower in the free-floating mat than in the attached fraction ( $t$-test for independent samples: $\mathrm{p}=0.011$ and $\mathrm{p}=0.00003$, respectively) and in the brown mats ( $t$-test for independent samples: $\mathrm{p}=0.00003$; Table 4 ).

Fluorescence measurements (photon yield) were not different between the freefloating and attached mats (Table 5; repeated measures ANOVA, $p=0.883$ ). The photon yield was significantly higher in the brown mats than in the 2 others ( $p=$ 0.042). In general, the photon yields were maximal during March (Table 5).

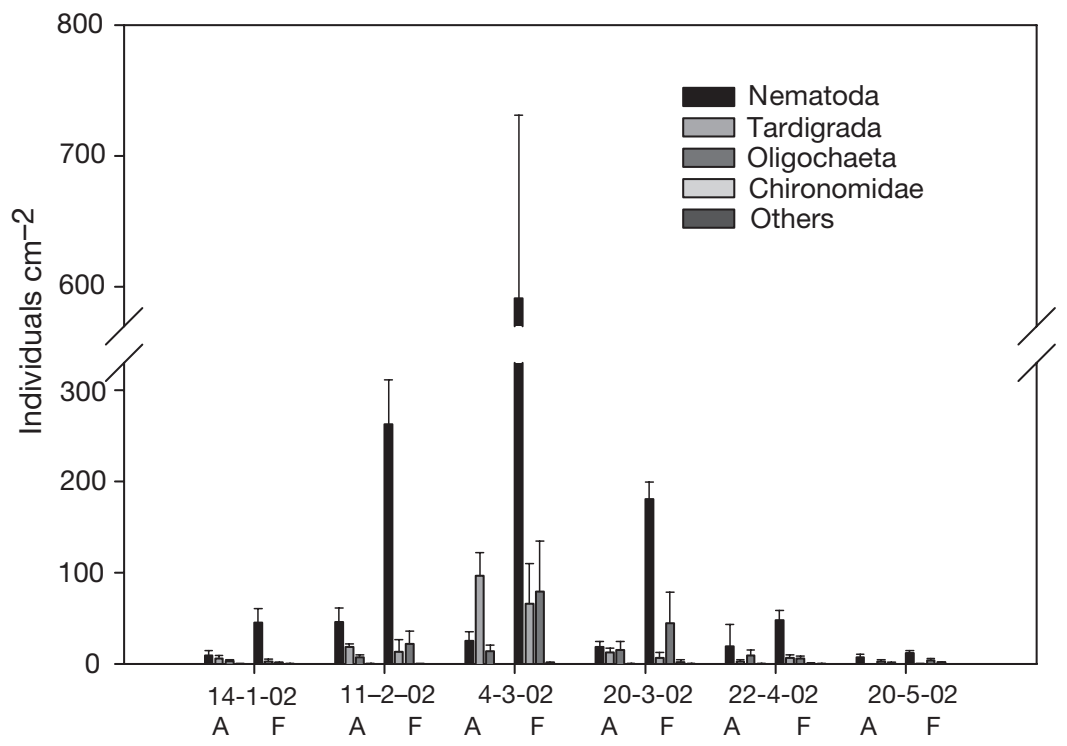

Fig. 4. Meiofauna (individuals $\mathrm{cm}^{-2}$ ) inhabiting the attached and the freefloating mats of the Llobregat River for some selected dates (d-mo-yr) of the study period. A: attached mat; F: free-floating mat

\section{Meiofauna}

Four meiofauna groups (Nematoda, Tardigrada, Oligochaeta and Chironomidae) inhabited the attached and free-floating mats (Fig. 4). Meiofauna den-

Table 4. Values of the phosphatase (APA) and aminopeptidase activity (AMA) ratio in the attached, free-floating and brown (diatom-dominated) mats, derived from the corresponding enzymatic activities during the studied period in the Llobregat River

\begin{tabular}{|lccc|}
\hline $\begin{array}{l}\text { Date } \\
(\mathrm{d} / \mathrm{mo} / \mathrm{yr})\end{array}$ & $\begin{array}{c}\text { Attached } \\
\text { mat }\end{array}$ & $\begin{array}{c}\text { Free-floating } \\
\text { mat }\end{array}$ & $\begin{array}{c}\text { Brown } \\
\text { mat }\end{array}$ \\
\hline $08 / 01 / 02$ & 0.149 & - & 0.264 \\
$14 / 01 / 02$ & 0.347 & 0.180 & 0.259 \\
$21 / 01 / 02$ & 0.262 & 0.181 & 0.218 \\
$28 / 01 / 02$ & 0.377 & 0.330 & 0.405 \\
$05 / 02 / 02$ & 0.368 & 0.100 & 0.280 \\
$11 / 02 / 02$ & 0.143 & 0.082 & 0.254 \\
$19 / 02 / 02$ & 0.310 & 0.082 & 0.501 \\
$25 / 02 / 02$ & 0.378 & 0.092 & 0.169 \\
$04 / 03 / 02$ & 0.191 & 0.121 & 0.254 \\
$11 / 03 / 02$ & 0.124 & 0.037 & 0.130 \\
$20 / 03 / 02$ & 0.060 & 0.130 & 0.205 \\
$26 / 03 / 02$ & 0.053 & 0.036 & 0.197 \\
$02 / 04 / 02$ & 0.070 & 0.047 & 0.306 \\
$10 / 04 / 02$ & 0.121 & 0.048 & 0.232 \\
$16 / 04 / 02$ & 0.097 & - & 0.223 \\
$22 / 04 / 02$ & 0.225 & 0.167 & 0.117 \\
$29 / 04 / 02$ & 0.226 & 0.129 & 0.249 \\
$20 / 05 / 02$ & 0.160 & 0.144 & 0.213 \\
$28 / 05 / 02$ & 0.203 & 0.131 & 0.292 \\
\hline
\end{tabular}

sity was lower in the attached (less than 150 ind. $\mathrm{m}^{-2}$ ) than in the free-floating cyanobacterial mat (maximum of 737 ind. $\mathrm{m}^{-2}$ ). Differences in meiofauna density between the two were higher between February and March (repeated measures ANOVA, p = 0.0001), coinciding with the maximum growth of the mats. The free-floating mat had a significantly higher number of Nematoda (repeated measures ANOVA, $\mathrm{p}=0.0004$ ).

Table 5. Values of photon yield (relative units of fluorescence) estimated for the attached, free-floating and brown (diatomdominated) mats, estimated in the field during the studied period in the Llobregat River

\begin{tabular}{|lccc|}
\hline $\begin{array}{l}\text { Date } \\
(\mathrm{d} / \mathrm{mo} / \mathrm{yr})\end{array}$ & $\begin{array}{c}\text { Attached } \\
\text { mat }\end{array}$ & $\begin{array}{c}\text { Free-floating } \\
\text { mat }\end{array}$ & $\begin{array}{c}\text { Brown } \\
\text { mat }\end{array}$ \\
\hline $14 / 01 / 02$ & 0.534 & 0.4376 & - \\
$21 / 01 / 02$ & 0.5137 & 0.5987 & 0.5273 \\
$28 / 01 / 02$ & 0.541 & 0.510 & 0.535 \\
$05 / 02 / 02$ & 0.5012 & 0.5269 & 0.5402 \\
$11 / 02 / 02$ & 0.4638 & 0.4963 & 0.5676 \\
$19 / 02 / 02$ & 0.2451 & 0.3428 & 0.5726 \\
$25 / 02 / 02$ & 0.3651 & 0.3924 & 0.5758 \\
$04 / 03 / 02$ & 0.4272 & 0.487 & 0.5947 \\
$11 / 03 / 02$ & 0.3103 & 0.4344 & 0.5128 \\
$20 / 03 / 02$ & 0.2957 & 0.4022 & 0.3591 \\
$26 / 03 / 02$ & 0.3526 & 0.442 & 0.4864 \\
$02 / 04 / 02$ & 0.4673 & 0.5189 & 0.5057 \\
$10 / 04 / 02$ & 0.4547 & 0.4563 & 0.5392 \\
$16 / 04 / 02$ & 0.4518 & - & 0.4996 \\
$22 / 04 / 02$ & 0.3663 & 0.3644 & 0.5036 \\
$29 / 04 / 02$ & 0.4674 & 0.507 & 0.4316 \\
\hline
\end{tabular}


The number of Oligochaeta and Tardigrada was also higher in the free-floating mat, but the differences were not significant.

\section{DISCUSSION}

Low turbulence and nutrient-rich conditions favour cyanobacterial growth (Paerl 1996). Low N:P ratios (Reynolds 1999, Smith \& Bennett 1999) or high nutrient concentrations in general (Downing \& Watson 2001) are believed to cause massive growths of planktonic cyanobacteria. The mass growth of Oscillatoria mats in the Llobregat River occurred when there was a high phosphorus content in the water, combined with a low availability of nitrogen (low N:P ratios) (Vilalta et al. 2003). Low flow and full light availability, in spite of low water temperature (Table 1), completed a favourable environmental scenario for the mass development of benthic cyanobacteria in the Llobregat River, which therefore resembled that described for planktonic outgrowths. The chl a concentrations (200

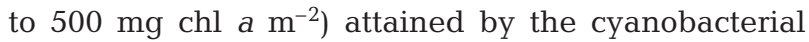
masses in the Llobregat River were among those commonly found in eutrophic situations elsewhere (Dodds et al. 1997, Romaní \& Sabater 2000).

Even though the low N:P ratio in the Llobregat River water was coincident with the mass growth of cyanobacteria, clearer evidence of nitrogen limitation by benthic cyanobacteria is required. The use of enzymatic activities as a proxy for nutrient limitation has been proposed for several environments and situations (Whitton 1991, Vrba et al. 1995, Cotner et al. 1997, Hoppe et al. 1998). AMA hydrolyses peptides and proteins, which comprise the largest part of the organic $\mathrm{N}$ pool (Halemejko \& Chróst 1986). High AMA levels indicate that inorganic nitrogen is being obtained from organic sources, which is what occurs when inorganic nitrogen availability is low (Patel et al. 2000, Sala et al. 2001). In the Llobregat River, there is a high concentration of nitrate but lower values of ammonia (Table 1), which could result in a disadvantage for cyanobacteria in the light-limited conditions inside the mat (Oliver \& Ganf 2000). APA converts phosphorus from organic molecules into inorganic phosphorus, and low values suggest that phosphorus is not limiting the metabolism of bacteria or primary producers (Chróst 1990). The ratio APA:AMA may be a useful summary of whether nutrient limitation is due to phosphorus or nitrogen availability (Sala et al. 2001). Different APA:AMA ratios were observed for the different cyanobacterial communities (free-floating, attached) as well as for the diatom brown mats. However, nutrient content was not significantly different between riffle zones and pool areas. This suggests that the specific enzymatic behaviour in the cyanobacterial mats, especially in the free-floating mats (where AMA levels were higher) might be related to their microhabitat conditions or specific mat physiology. Nutrient depletion in the mats is related to thickness and associated difficulties in diffusion of resources (Sabater et al. 2002). This might be higher in drifting masses, where replacement of overflowing waters can be much slower than in the attached compartment. Nitrogen limitation by the Oscillatoria mats would be related to its low enzymatic APA:AMA ratio. The observation of suspected nitrogen limitation is consistent with the non-heterocystous nitrogen-fixer character described for this cyanobacteria (Villbrandt et al. 1990).

Cyanobacterial toxins and odour/taste metabolites may be regulated by complex environmental factors affecting the physiological state and growth stage (Paerl \& Millie 1996). The synthesis of these metabolites may be interpreted as a mechanism for dissipating excess carbon during changes in physiological state (Naes et al. 1985) which may arise during growth. In fact, in the Llobregat River, cyanobacteria mass production was coincident with a peak of the odorous metabolite, geosmin, suggesting that the ecological mechanisms behind its production were linked to cyanobacteria mass growth. The lower quantum yield characteristic of the cyanobacterial mats (free-floating and attached) could not be related to geosmin occurrence. The attached mat possibly plays an important role in geosmin production and, once developed into the free-floating form, may become important in geosmin release and dispersion following cell lysis processes. Synthesis of geosmin in culture has been linked to the alteration of cell growth caused by nutrient deficiency (Wu et al. 1991). Bafford et al. (1993) confirmed that geosmin was present even in young cells of Oscillatoria limosa, but Wu et al. (1991) found that geosmin increased during the lag-phase of growth, when the population was not at its optimum. Naes \& Post (1988) observed that transient changes of light and nitrogen could only explain a fraction of geosmin occurrence by cyanobacterial populations, and concluded that biomass level could be a critical factor. Therefore, geosmin synthesis may be controlled by the growth rate of the cells in a community. Declining growth, which in the Llobregat River may be related mainly to nitrogen scarcity, might result in an increase in geosmin.

While nitrogen limitation may act as a trigger for the increase of geosmin within the cyanobacterial mats, physiological differences between the attached and the free-floating compartments indicate that mechanisms at work diverge. The specific high AMA observed in the free-floating mat may be related to the decay dynamics of the mat, where cell lysis processes 
could be relevant. Lower APA:AMA ratios were recorded from March to early April both in the attached and free-floating mats (Table 4), when geosmin production was maximum. A further indication of decay is the joint increase of AMA and $\beta$ glucosidase that characterises the evolution of this compartment. Similar patterns have been observed following the spring phytoplankton bloom in lakes (Halemejko \& Chróst 1986, Chróst 1989), since degradation and lysis of senescent algal cells leads to a release of proteinaceous and polysaccharidic compounds (Middelboe et al. 1995). Furthermore, these patterns in the Llobregat River underlie the possible relationship between the degradation processes occurring within the mat and the release of geosmin into the water.

Geosmin is bound to cell structures, such as chloroplast lamellae and lipophylic cell materials (Wu \& Jüttner 1987). Therefore, this metabolite does not leave the cell except by cell lysis. In support of this view, it has been shown that treatment with chlorine, copper sulphate or potassium permanganate during water purification can cause geosmin increase in the water (Peterson et al. 1995, Chow et al. 1998). The suggested lysis process in the free-floating compartment is in agreement with the higher geosmin content found there. The meiofauna is not excluded from this process and may have a relevant role in enhancing cell lysis, and perhaps in stimulating geosmin synthesis. Meiofauna density was much higher in the free-floating mat compared to the attached mat, possibly because of the higher quality of this material. Lower $\mathrm{C}: \mathrm{N}$ ratio and higher polysaccharide content in the free-floating mat compared to the attached mat (Table 3) may favour greater development of meiofauna in that compartment, both directly and via bacterial growth. The availability and the quality of organic matter strongly influence survival, development time, growth and reproduction of invertebrates (Cummins \& Klug 1979). Lenting et al. (1997) and Palmer et al. (2000) observed that meiofauna abundance was greater in substrates with high microbial biomass or low $\mathrm{C}: \mathrm{N}$ content. Apart from the nutritional value, lower sediment particles could result in a better habitat for meiofauna in the free-floating mats of the Llobregat River. Whatever the reason for their extensive development in the cyanobacterial mats, and especially in the free-floating ones, meiofauna can contribute both to the degradation activity and to the transport and diffusion of geosmin. Suspected grazing and the movement of meiofauna through interstitial spaces may increase permeability (Boulton et al. 2002) and, therefore, enhance dispersion of the mat in its travel down river. It has been observed elsewhere that the release of geosmin from planktonic cyanobacteria was deter- mined by zooplankton grazing (Durrer et al. 1999), while ciliates were effective in grazing geosmin-producing cyanobacteria (Sudo et al. 1989). In the Llobregat River, because they are being transported passively downstream, the free-floating mats contribute enormously to the potential distribution of geosmin in the river. In this process, the link between the cyanobacterial dynamics and the meiofauna inhabiting the mats may be essential in determining the waning of the mats and the related geosmin diffusion into the river water.

Acknowledgements. This study was funded by the European Project 'BIOFILMS' (EVK1-1999-00005). Thanks are due to Enrique Navarro for help during field work. Aigües Ter Llobregat (ATLL) carried out the geosmin analyses. Useful comments from several anonymous reviewers are much appreciated.

\section{LITERATURE CITED}

Alcaraz R, Valero F, Guasch H, Sabater S (2002) Application of purge and trap (P\&T) technique for geosmin determination in water and biofilm. 7th Int Symp Anal Methodology Environ Field, Valladolid

Bafford RA, Seagull RW, Chung SY, Millie DF (1992) Intracellular localization of the taste/odor metabolite, 2methylisoborneol, in Oscillatoria limosa (Cyanophyta). J Phycol 28:11-18

Baker PD, Steffensen DA, Humpage AR, Nicholson BC, Falconer IR, Lanthois B, Fergusson KM, Saint CP (2001) Preliminary evidence of toxicity associated with the benthic cyanobacterium Phormidium in South Australia. Environ Toxicol 16:506-511

Boulton A, Hakenkamp C, Palmer M, Strayer D (2002) Freshwater meiofauna and surface water-sediment linkages: a conceptual framework for cross-system comparisons. In: Rundle SD, Robertson AL, Schmid-Araya JM (eds) Freshwater meiofauna: biology and ecology. Backhuys Publishers, Leiden, p 241-259

Chow CWK, House J, Velzeboer RMA, Drikas M, Burch MD, Steffensen DA (1998) The effect of ferric chloride flocculation on cyanobacterial cells. Water Res 32:808-814

Chróst RJ (1989) Characterization and significance of $\beta$ glucosidase activity in lake water. Limnol Oceanogr 34: 660-672

Chróst RJ (1990) Microbial ectoenzymes in aquatic environments. In: Overbeck J, Chróst RJ (eds) Aquatic microbial ecology: biochemical and molecular approaches. Springer Verlag, New York, p 47-78

Codd GA (1995) Cyanobacterial toxins: occurrence, properties and biological significance. Water Sci Technol 32: $149-156$

Cotner JB, Ammerman JW, Peele ER, Bentzen E (1997) Phosphorus-limited bacterioplankton growth in the Sargasso Sea. Aquat Microb Ecol 13:141-149

Cummins KW, Klug MJ (1979) Feeding ecology of stream invertebrates. Annu Rev Ecol Syst 10:147-172

Dodds WK, Smith VH, Zander B (1997) Developing nutrient targets to control benthic chlorophyll levels in streams: a case study of the Clark Fork River. Water Res 31: $1738-1750$

Downing JA, Watson SB (2001) Predicting cyanobacteria dominance in lakes. Can J Fish Aquat Sci 58:1905-1908 
Dubois M, Giles KA, Hamilton JK, Rebers PA, Smith F (1956) Colorimetric method for the determination of sugars and related substances. Anal Chem 28:350-356

Durrer M, Zimmermann U, Juttner F (1999) Dissolved and particle-bound geosmin in a mesotrophic lake (Lake Zurich): spatial and seasonal distribution and the effect of grazers. Water Res 33:3628-3636

Grasshoff K, Ehrhardt M, Kremling K (1983) Methods of seawater analysis, 2nd edn (revised and extended). Verlag Chemie, Weinheim

Halemejko GZ, Chróst RJ (1986) Enzymatic hydrolysis of proteinaceous particulate and dissolved material in an eutrophic lake. Arch Hydrobiol 107:1-21

Hamill KD (2001) Toxicity in benthic freshwater cyanobacteria (blue-green algae): first observations in New Zealand. NZ J Mar Freshw Res 35:1057-1059

Hofstraat JW, Peeters JCH, Snel JFH, Geel C (1994) Simple determination of photosynthetic efficiency and photoinhibition of Dunaliella tertiolecta by saturating pulse fluorescence measurements. Mar Ecol Prog Ser 103:187-196

Hoppe HG, Giesenhagen HC, Gocke K (1998) Changing patterns of bacterial substrate decomposition in a eutrophication gradient. Aquat Microb Ecol 15:1-13

Izaguirre G, Taylor WD (1995) Geosmin and 2-methylisoborneol production in a major aqueduct system. Water Sci Technol 31:41-48

Jeffrey SW, Humphrey GF (1975) New spectrophotometric equations for determining chlorophylls $\mathrm{a}, \mathrm{b}$, and $\mathrm{c}$ in higher plants, algae and natural phytoplankton. Biochem Physiol Pflanz 167:191-194

Lenting N, Williams DD, Fraser BG (1997) Qualitative differences in interstitial organic matter and their effect on hyporheic colonisation. Hydrobiologia 344:19-26

Mez K, Hanselmann K, Preisig HR (1998) Environmental conditions in high mountain lakes containing toxic benthic cyanobacteria. Hydrobiologia 368:1-3

Middelboe M, Sondergaard M, Letarte Y, Borch NH (1995) Attached and free-living bacteria: production and polymer hydrolysis during a diatom bloom. Microb Ecol 29: 231-248

Naes H, Post AF (1988) Transient stages of geosmin, pigment, carbohydrates and proteins in continuous cultures of Oscillatoria brevis induced by changes in nitrogen supply. Arch Microbiol 150:333-337

Naes $H$, Aarnes H, Utkilen HC, Nilsen S, Skulberg OM (1985) Effect of photon fluence rate and specific growth rate on geosmin production in the cyanobacterium Oscillatoria brevis (Kütz.) Gom. Appl Environ Microbiol 49:1538-1540

Oliver RL, Ganf GG (2000) Freshwater blooms. In: Whitton BA, Potts M (eds) The ecology of cyanobacteria. Kluwer Academic, Dordrecht, p 149-194

Paerl HW (1996) A comparison of cyanobacterial bloom dynamics in freshwater, estuarine and marine environments. Phycologia 35:25-35

Paerl HW, Millie DF (1996) Physiological ecology of toxic aquatic cyanobacteria. Phycologia 35:160-167

Palmer MA, Swan CM, Nelson K, Silver P, Alvestad R (2000) Streambed landscapes: evidence that stream invertebrates respond to the type and spatial arrangement of patches. Landscape Ecol 15:563-576

Patel AB, Fukami K, Nishijima T (2000) Regulation of seasonal variability of aminopeptidase activities in surface and bottom waters of Uranouchi Inlet, Japan. Aquat Microb Ecol 21:139-149

Editorial responsibility: Edna Granéli, Kalmar, Sweden
Peterson HG, Hrudey SE, Cantin IA, Perley TR, Kenefick SL (1995) Physiological toxicity, cell membrane damage and the release of dissolved organic carbon and geosmin by Aphanizomenon flos-aquae after exposure to water treatment chemicals. Water Res 29:1515-1523

Pringault O, Garcia Pichel F (2000) Monitoring of oxygenic and anoxygenic photosynthesis in a unicyanobacterial biofilm, grown in benthic gradient chamber. FEMS Microbiol Ecol 33:251-258

Reynolds CS (1999) Non-determinism to probability, or N:P in the community ecology of phytoplankton. Arch Hydrobiol 146:23-35

Romani AM, Sabater S (2000) Influence of algal biomass on extracellular enzyme activity in river biofilms. Microb Ecol 40:16-24

Sabater S, Armengol J, Sabater F, Comas E, Urrutia I, Urrizalqui I (2000) Algal biomass in a disturbed Atlantic river: water quality relationships and environmental implications. Sci Total Environ 263:185-195

Sabater S, Guasch H, Romani A, Munoz I (2002) The effect of biological factors on the efficiency of river biofilms in improving water quality. Hydrobiologia 469:149-156

Sala MM, Karner M, Arin L, Marrase C (2001) Measurement of ectoenzyme activities as an indication of inorganic nutrient imbalance in microbial communities. Aquat Microb Ecol 23:301-311

Smith VH, Bennett SJ (1999) Nitrogen:phosphorus supply ratios and phytoplankton community structure in lakes. Arch Hydrobiol 146:37-53

Stal LJ (1995) Physiological ecology of cyanobacteria in microbial mats and other communities. New Phytol 131: $1-32$

Sudo R, Inamori Y, Kuniyasu Y, Ouchiyama T (1989) Predation and deodorization of musty odor-producing filamentous algae by the protozoa Trithigmostoma cucullulus. Water Pollut Res Control 21:1743-1746

Vilalta E, Guasch H, Muñoz I, Navarro E, Romaní AM, Valero F, Rodríguez JJ, Sabater S (2003) Ecological factors that co-occur with geosmin production by benthic cyanobacteria. The case of the Llobregat River. Arch Hydrobiol Algol Stud 109:579-592

Villbrandt M, Stal LJ, Krumbein WE (1990) Interactions between nitrogen fixation and oxygenic photosynthesis in a marine cyanobacterial mat. FEMS Microbiol Ecol 74: $59-72$

Vrba J, Vyhnalek V, Hejzlar J, Nedoma J (1995) Comparison of phosphorus deficiency during a spring phytoplankton bloom in a eutrophic reservoir. Freshw Biol 33:73-81

Whitton BA (1991) Use of phosphatase assays with algae to assess phosphorus status of aquatic environments. In: Jeffrey DW, Madden B (eds) Bioindicators and environmental management. Academic Press, London, p 295-310

Winer BJ (1971) Statistical principles in experimental design. McGraw Hill, New York

Wu TJ, Jüttner F (1987) Effect of environmental factors on geosmin production by Fischerella muscicola. In: Persson $\mathrm{PE}$, Whitfield FB, Motohiro $\mathrm{T}$ (eds) Off flavours in the aquatic environment. Proc 2nd Int Assoc Water Pollut Res Control Symp, Vol 20. Kagoshima, p 8-9

Wu JT, Ma PI, Chou TL (1991) Variation of geosmin content in Anabaena cells and its relation to nitrogen utilization. Arch Microbiol 157:66-69

Young WF, Horth H, Crane R, Ogden T, Arnott M (1996) Taste and odour threshold concentrations of potential potable water contaminants. Water Res 30:331-340

Submitted: December 23, 2002; Accepted: March 24, 2003

Proofs received from author(s): May 7, 2003 